\title{
Retraction Note to: Integrated physiological and proteomic analysis of embryo and endosperm reveals central salt stress response proteins during seed germination of winter wheat cultivar Zhengmai 366
}

Dongmiao Liu ${ }^{1 \dagger}$, Caixia Han ${ }^{1 \dagger}$, Xiong Deng ${ }^{1 \dagger}$, Yue Liu ${ }^{1}$, Nannan Liu ${ }^{1}$ and Yueming Yan ${ }^{1,2^{*}}$

Retraction note: BMC Plant Biology(2019) 19:29

https://doi.org/10.1186/s12870-019-1643-z

The editor has retracted this article [1] because parts of Figs. 1 and 4 were duplicated from a previously published paper by the same authors [2] without appropriate disclosure. None of the authors have responded to any correspondence from the editor about publication of this retraction notice.

Published online: 17 September 2019

\section{References}

1. Liu, et al. Integrated physiological and proteomic analysis of embryo and endosperm reveals central salt stress response proteins during seed germination of winter wheat cultivar Zhengmai 366. BMC Plant Biol. 2019; 19:29. https://doi.org/10.1186/s12870-019-1643-z.

2. Liu, et al. Integrated physiology and proteome analysis of embryo and endosperm highlights complex metabolic networks involved in seed germination in wheat (Triticum aestivum L.). J Plant Physiol. 2018;229:63-76. https://doi.org/10.1016/j.jplph.2018.06.011.

\footnotetext{
* Correspondence: yanym@cnu.edu.cn

${ }^{+}$Dongmiao Liu, Caixia Han and Xiong Deng contributed equally to this work.

${ }^{1}$ Laboratory of Molecular Genetics and Proteomics, College of Life Science, Capital Normal University, Beijing 100048, China

${ }^{2}$ Hubei Collaborative Innovation Center for Grain Industry (HCICGI), Yangtze

University, Jingzhou 434025, China
}

(c) The Author(s). 2019 Open Access This article is distributed under the terms of the Creative Commons Attribution 4.0 International License (http://creativecommons.org/licenses/by/4.0/), which permits unrestricted use, distribution, and reproduction in any medium, provided you give appropriate credit to the original author(s) and the source, provide a link to the Creative Commons license, and indicate if changes were made. The Creative Commons Public Domain Dedication waiver (http://creativecommons.org/publicdomain/zero/1.0/) applies to the data made available in this article, unless otherwise stated. 